\title{
Struggle for Mobility: Risk, Hope and Community of Knowledge in Eritrean and Ethiopian Migration pathways towards Sweden
}

Thèse de Doctorat (PhD), Department of Social Anthropology, Stockholm University, 2017, $251 \mathrm{p}$.

Tekalign Ayalew Mengiste

\section{OpenEdition}

\section{Journals}

Electronic version

URL: http://journals.openedition.org/anthropodev/614

DOI: $10.4000 /$ anthropodev.614

ISSN: 2553-1719

Publisher

APAD - Association pour l'anthropologie du changement social et du développement

Printed version

Date of publication: 1 December 2017

Number of pages: $265-267$

ISBN: 979-10-93476-05-6

ISSN: 2276-2019

\section{Electronic reference}

Tekalign Ayalew Mengiste, « Struggle for Mobility: Risk, Hope and Community of Knowledge in Eritrean and Ethiopian Migration pathways towards Sweden », Anthropologie \& développement [Online], 46-47 |

2017, Online since 01 December 2017, connection on 24 September 2020. URL : http://

journals.openedition.org/anthropodev/614; DOI : https://doi.org/10.4000/anthropodev.614

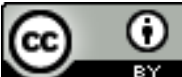

La revue Anthropologie \& développement est mise à disposition selon les termes de la Licence Creative Commons Attribution 4.0 International. 


\title{
Struggle for Mobility: Risk, Hope and Community of Knowledge in Eritrean and Ethiopian Migration pathways towards Sweden
}

\author{
Tekalign Ayalew Mengiste ${ }^{1}$ \\ Thèse de Doctorat (PhD), Department of Social Anthropology, Stockholm \\ University, 2017, $251 \mathrm{p}$.
}

\begin{abstract}
This study examines the motivations, organizations and impact of overland migratory journeys from Ethiopia and Eritrea across the Sahara Desert and Mediterranean Sea to Sweden. The analysis involves the exploring of how migrants strive to prepare, manage and survive the multiple risks and structural barriers they encounter: the exits from Eritrea and Ethiopia, negotiations and contacts with various brokers and facilitators, organized crime and violence, restrictive border controls, passage through the Desert and high Sea and finally, 'managing the asylum system in Sweden'. Further, it maps how the process of contemporary refugee mobility and multiple transitions is facilitated by the entanglement of transnational social relations and smuggling practices. The study argues for a perspective wherein migration journeys are embedded and affected by the process of dynamic intergenerational, translocal and transnational social relations, material practices and knowledge productions. It depicts how practices and facilitations of irregular migratory mobility contribute to reproduce collective knowledge that refugees mobilize to endure risks during their journey, establishing a community and creating a home after arriving at the destination location.
\end{abstract}

Based on multi-sited ethnographic fieldwork in Stockholm (Sweden), Addis Ababa (Ethiopia), Khartoum (Sudan) and Rome (Italy), conducted between 2013 and 2015, the thesis sets out to problematize simplistic push-pull models in conventional migration theory and contributes to the new literature on the lives of illegalized migrants and refugees and their relationships to human smugglers. The thesis further critically examines the problematic categorizations of refugees and economic migrants by depicting how the forced-voluntary division could be seen as a continuum rather than clear dichotomy.

${ }^{1}$ E-mail : tekalign.ayalew@socant.su.se 
The ethnography produced for the thesis consists of 94 in-depth interviews with interlocutors and an almost equal number of women and men, including 35 detailed individual migration narratives. Five smugglers were also interviewed each providing insights into a particular leg of the migration pathways. Primary data findings were also supplemented through reviewing research, policy and critical media reports on contemporary refugee mobility from the Horn of Africa and practices of human smuggling across Euro-African borderlands and beyond. Above all, I took advantage of my partial insider position: I speak the language my informants spoke, lived migrants' daily lives in destination countries, and experienced the same borders where they were stopped, interrogated or denied visas as they travelled in Europe. These events helped me collect in-depth, corroborated data.

Theoretically, the analysis builds up on three key concepts: Risk, hope and community of knowledge. I argue that high-risk migration should be seen less as a choice to engage in risky behavior and more as a process necessary to survive and make life less risky in later stages. In the analysis High-risk migration or trajectory, encompasses perceptions, engagements and experiences regarding the unauthorized crossings of highly militarized borders, dangerous journeys across deserts and the Sea towards a desired destination; leading a vulnerable life as undocumented migrants in the destination country and deportations and remigrations. The adjective 'high' in 'high-risk migration' refers to the magnitude of danger: injury, kidnaping, imprisonment, rape, torture or death.

Hope is a future orientation and when related to migration it is about securing a better future that becomes a key condition in migration decisions. Hope is not an individual mental conditions, instead it is search for future certainty that is produced with and through others. In the context of migration, hope has temporal and spatial dimensions. It is about feeling that 'now and here' there are risks but 'there and then' there is hope for better conditions and opportunities, despite the risk of losing one's life (e.g. when crossing vast deserts and high seas using unsafe means).

To capture the emergence of smuggling networks and the role of transnational diasporic engagements in facilitating refugee mobility and multiple transitions I introduce the concept of community of knowledge, which could be read as all types of useful information and 'common sense' knowledge generated by and embedded in migrant networks and contacts during their journey and which in itself creates dynamic transnational social spaces constituting migration pathways. Often disregarded as simply advise or 'common sense information', migration knowledge is generated by and embedded in the everyday dynamics of refugee 
communities and transmitted during their migration journeys, creating a dynamic transnational protective sphere.

The analysis revealed the following findings. High-risk migration - grounded in historical, political and economic crises that reproduce protracted insecurities - is indeed risky, but also a path of hope. High-risk migration does not imply a linear journey to Europe, but is fragmented, stepwise and somewhat unpredictable; migratory journeys are produced in complex social relations; and knowledge is produced along the way. Migrants' experiences of violence along the trail is not merely about greedy smugglers, but part of structural conditions that serves to maintain local and global inequality in part through the unequal access to safe and formal means of mobility. The struggle for mobility has detrimental effects on migrants' bodies, emotions and legal statuses, reproducing migrants as a commodity comparable to transatlantic slave trade. Transnational social migration infrastructures inform, mediate and sustain high-risk migration journeys and link sending, transition and receiving locations, providing refugees on the move, protection from below. 